\title{
Social Isolation of the Stateless and the Destitute: A Study on the Refugee-Camp and the Sullied Slum of Dhaka City
}

\author{
Muhammad Rehan Masoom \\ School of Business \& Economics, United International University, UIU Bhaban, House No. 80, Road No. 8/A (Old 15), \\ Satmosjid Road, Dhanmondi, Dhaka 1209, Bangladesh
}

Correspondence should be addressed to Muhammad Rehan Masoom; rehan_1611@yahoo.com

Received 15 December 2015; Accepted 14 February 2016

Academic Editor: Thomas Panagopoulos

Copyright (C) 2016 Muhammad Rehan Masoom. This is an open access article distributed under the Creative Commons Attribution License, which permits unrestricted use, distribution, and reproduction in any medium, provided the original work is properly cited.

The lower-class segment of the population of the developing nations often fails to form meaningful social relations and remain disengaged from essential social institutions. The research examines those people who live in refugee-camp and sullied slum of Dhaka city and inspect how much they are socially isolated. Certain characteristics, taken as indicators to test the level of social isolation, indicate that a large segment of camp and slum dwellers are feeling isolated. However, the evidence shows no differences in the predicted direction with respect to the objective demographic variables; nonetheless, a pattern of perceived social isolation was found from the survey data.

\section{Introduction}

Dhaka, capital city of Bangladesh, is the place of 32 slumlike settlements, known as "refugee-camps" [1]. These are "the home" for a large number of politically excluded Urduspeaking people, who have non-Bengali origins. During the Partition of British-India in 1947, they willingly have migrated from the present day Indian provinces of Bihar, Uttar Pradesh, Madhya Pradesh, and Rajasthan to the present day Bangladesh [2]. During the liberation war in 1971, they, as of non-Bengali origin, showed allegiance toward the West Pakistani regime and opposed the Bengalis' freedom struggle. Hence, when two wings of the Pakistan were being separated, this fairly large number of people is supposed to be repatriated to the present day Pakistan. However, due to complication in the repatriation process, they failed and were forced to live in 116 squalid camps in several districts around Bangladesh [3]. Some people addressed them as "Stranded Pakistanis" or "Urdu speaking people"; some others may regard them Muhajirs, Indian-Bangladeshis, nonlocals, and non-Bangladeshis, but none has ever called them Bangladeshis. Further, the cessation clauses of the 1951 Convention and the United Nations High Commissioner for Refugees (UNHCR) Statutes of 1950 regards them as "nonrefugees" due to the fact that they are not forcefully migrated from their place of origin to the place of migration [4]. They have never assimilated themselves with the local Bangladeshi people, and now they or their decedents are not getting any options to do so. They are being deprived of all sorts of basic amenities that any citizen should have access to [5].

Dhaka city is also the home of over 12 million inhabitants [6]. The prospects of the city lie in solving problems of inefficient management and planning, weak urban services, pervasive corruption, unbearable traffic congestion, intolerable environmental hazard, and food contamination. It is the second least livable city among the world's 140 cities on "Global Livability Index" in 2014, as indicated by the Economist Intelligence Unit. Despite all these miseries, like all the capital cities around the world, Dhaka offers better income opportunities than most parts of the country and hence faces rapid migration and fast urbanization. Besides, due to environmental hardship, some 500,000 people move to the capital, Dhaka, from coastal and rural areas each year [7]. Most of the migrants end up in the sullied slums, home to an estimated 3.5 million people-40 percent of the city's population [8]. The city faces tremendous challenges due to lack of a comprehensive urban policy and this resulted in having slums with a large number of populations. Nearly 80 percent of these slums are located on the lands that are privately owned [9]. These slums are commonly characterized 
by poor housing, shortage of water, improper sanitation and drainage system, irregular electricity supply, polluted air, and lack of urban governance [10]. There are hardly any social support services that are accessible to the slum dwellers due the three basic factors: (1) a lack of government policy giving slum residents rights and access; (2) the eviction of slum residents; and (3) the role of musclemen or middlemen in the absence of formal government structures [11].

These camps and slum dwellers, whether being isolated due to sociopolitical situation or not economically well off, have the common ground of not having enough confidence to bring positive changes for them by participating in the social aspects and developing social relations. Whether the issue is political mistreatment or poverty, these people are coming to consider it as neither having had control over that nor being able to bring changes to that. Although they are very much aware about their very situation and how it is shaping their personal and social lives, however, some of their futile attempts to change these exasperating states of affairs eventually leave them utterly frustrated [12]. This may have a negative impact on self-esteem and consequently reduces the social and economic opportunities. This is due in part to a feeling among at least some of them that they are socially isolated in the face of an unresponsive and uncaring society. This very feeling of isolation can lead to a failure to be associated with society and social progress and thus can bring severe negative consequences. This paper defines "Social Isolation" as the loss of social relations and disengagement from essential social institutions and portrays a picture of socially isolated people who are living in slum and refugee-camp in Dhaka City. "Theoretical framework" of this research seeks to offer the conceptual analysis formulated by examining the classical and contemporary sociological concepts, and addresses the proper procedure to measure subjective perception of "Social Isolation" among the plethora of measurement scales.

\section{Theoretical Framework}

Urban lives centered more on day-to-day interactions and less on long-term relationships. Hence, merely "impersonal, superficial, transitory, and segmental" contacts are formed [13]. Evidently, social isolation is more pronounced among the migrants than that of the other marginalized groups. Experiences of being rootlessness and inability to form satisfactory personal ties in the new conditions isolate the migrants from the dominant local culture and amplify psychosocial loneliness [14]. Due to cultural differences, such as in ascent or language, the migrants are often unable to form intimacies with people around them and fail to construct a decent social identity. Social identities guide behaviors, make any social acts meaningful, and are enacted in social relationships. Therefore, failure to form a decent identity leads to mislaying the competence of functioning in interpersonal relations [15]. It is a set of difficulties that begin with the feeling of alienation and experiencing relational complications that eventually lead to interpersonal impediments. More often than not, the long-term noninvolvement in the formal economy increases the vulnerability of becoming poor and subsequently becoming poor makes it more problematic to return to a proper employment. Thus, a vicious circle of exclusion is being created [16]. Although social isolation and unemployment may not be directly related, the problem of poverty is a common trait among the socially isolates. Further, living in a very poor neighborhood increases social isolation and reduces access to social resources [17]. Any effort to be secured in formal employment in any labor market is, more often than not, characterized by expanding dependencies upon nonpoor neighbors and personal contacts [18].

Social isolation is rampant if any individuals lack social support that includes both tangible and emotional support along with the support of the acts of others [19]. It is found that, despite the equal level of satisfaction with the available social support network, men were more isolated than women, primarily because the contention that men, in general, satisfy their emotional needs by having discussion with their spouses, while women satisfy their needs by talking with their female friends [20]. Sometimes, people begin to consider themselves as socially isolated merely due to the fact that they may have failed to acquire a good education and proper respectable job. This results in the belief that they may face an acquisition of being corrupt quite unreasonably by the respectable part of the society. Hence, they begin to consider themselves being rejected by members of respectable society and decide to disengage from the larger community. Ironically, they begin to get less opportunity to become a part of integrated society equally with those who are truly accused of being corrupt [21].

Although there is an agreement on the overall concept of social isolation in the body of theoretical work, nevertheless, more often than not, empirical investigations proposed by different researchers reveal inconsistency in adopting appropriate indicators. Researches on perceived social isolation of poor have been relatively diversified due to some unstated and untested indicators and often been hampered by ethnocentric attitudes. Another major issue is whether to use objective indicators to measure sociopolitical situation and economic conditions of the target population or the focus should be on the quality of the social relationships that they have. Another way to speak, there is a dilemma to study social isolation, either in the macrolevel, by relating to the historical context and social circumstances, or using proposed scales, a microlevel analysis, to measure the perception to reach conclusions about the level of social isolation. The problems of measurement follow from the problems of proper indicators. Indicators are either objective-a specific set of observable phenomena that can be identified and replicated-or subjective-nonobservable and varies from researcher to researcher.

The first question is to figure out what are the perceived elements to be singled out that can be used as conducive indicators of social isolation. While several investigators have successfully demonstrated the feasibility of some kinds of contextual measurement approaches, there is a dearth of methodological information on multiple-item, multidimensional, context-bound measures of social Isolation. One 
major source of problem to measure social isolation is to relate this with sociopolitical and socioeconomic circumstances of the respondents who are feeling isolated. The subjective scales, developed and used by many renowned researchers to measure the degree of social isolation, are more effective and less intricate than that of theoretical discussed variables proposed by classical theorists. Among the researchers, Jaco [22], Seeman [23], Dean [24], Waisanen [25], and Weiss [26] are prominent to develop measurement scale to determine the level of isolation of a group of people.

Jaco [22] proposes following array of factors can be regarded as provisional criteria of social isolation, (I) Anonymity, (II) High Spatial Mobility, (III) Remote Location of Friends, (IV) Low Frequency of Participation in Groups and Institutions, (V) Low Occupational Participation, and (VI) Low Frequency of Participation with Other Communities. The General Social Survey (GSS) in the United States of America used questions like "there is no one with whom they discuss important matters" to find out the social isolated in 1985 and in 2004. Seeman [23] has offered five different meanings of alienation: (1) powerlessness defined as the expectancy or probability held by the individual that his own behavior cannot determine the occurrence of the outcomes, or reinforcements, he seeks; (2) meaninglessness, a situation in which the individual is unclear as to what he ought to believe-when the individual's minimal standards for clarity in decision-making are not met; (3) normlessness, which occurs when there is high expectancy that socially unapproved behaviors are required to achieve given goals; (4) social isolation which indicates the assigned low reward value to goals or beliefs that are typically highly valued in the given society, and (5) self-estrangement which refers to the degree of dependence of the given behavior upon anticipated future rewards.

Dean [24] suggested a scale to measure social isolation, along with powerlessness and meaninglessness. The conceptual meanings of these are completely different from that of Seeman. Social Isolation, according to Dean, means the feeling of separation from the group or of isolation from group standards. He indicates powerlessness as helplessness and normlessness as purposelessness and conflicts of norms. Like Seeman and Dean, Waisanen [25] considers "social isolation" as a subdimension of alienation and indicates it as loosing affective ties with the people. The other subdimensions are normlessness that arises if the person lacks familiarity with the system's rules and norms and powerlessness that arises if any individual lacks power in exchange. Fischer [27] examined the theory derived from Wirth [13] that urban people are predominantly exposed to alienation. He considers two dimensions, (1) "powerlessness," which is operationalized with a sense of personal competence scale and (2) social isolation, which is operationalized by scales and items reflecting a distrust of others and interpretable as a sense of anomie. Examining these dimensions, he finds no association of size of Standard Metropolitan Statistical Area with powerlessness, whereas felt social isolation was weakly but consistently associated. Evidently, measuring powerlessness can be ignored. Weiss [26] indicates that social isolation arises from loneliness, which is a natural response to a particular situation. He considers feelings like emptiness, anxiety, restlessness, and marginality are the result of social isolation [26].

\section{Method}

The purpose of this paper is to report a study of the situation of perceived social isolation between the camp and slum dwellers. The reliability of the "social isolation" subscale of Dean's "powerlessness scale" tested by the split-half method and corrected by the Spearman-Brown formula is 0.84 . Due to its high level of reliability, this research measured "social isolation" by this social isolation subscale. The 9 items are presented in five-point Likert format, with answer alternatives ranging from 5 (Strongly Agree) to 1 (Strongly Disagree); five of the items are reverse-scored. Scale scores can vary from 9 (signifying lowest social isolation) to 45 (signifying highest social isolation). The survey assessed the ratio of responses in the categories like "Strongly Agree," "Agree," "Uncertain," "Disagree," or "Strongly Disagree" by the respondents. The survey was carried out from January 2015 to September 2015.

The total population of refugee-camps around the country is 261,055 . (There is hardly any official data regarding the total population of the refugee-camps around the country due to the fact that more often than not they have been dined their citizenship and not counted as the part of official population of the country. However, a nonprofit organization (registered under the laws of the State of Texas, USA) named "Stateless People in Bangladesh" indicates the mentioned number as total number of refugees in 2005.) The total population of slum in major cities around the country is 5.4 million [8]. Therefore, a rough estimation about the entire population of the encampment and the slum dwellers would be approximately $5,661,055$. The study considers 384 as its estimated sample size by using the following formula:

$$
\begin{aligned}
& x=Z\left(\frac{c}{100}\right)^{2} r(100-r), \\
& n=\frac{N x}{\left((N-1) E^{2}+x\right)}, \\
& E=\operatorname{Sqrt}\left[\frac{(N-n) x}{n(N-1)}\right],
\end{aligned}
$$

where $N$ (population size) $=5,661,055, r$ (the fraction of responses $)=50 \%, c$ (the confidence level $)=95 \%, Z(c / 100)$ is the critical value of $c, E$ (margin of error) $=5 \%$, Thus, recommended sample size $(n)=384$.

The survey was administered to samples of two discrete, yet similar, socially isolated groups of people, one who are living below the poverty-line, residing in slums, and the other, socially excluded, living in refugee-camp. Randomly sampled 384 individuals were interviewed using a standard questionnaire. The research considers the "Millat Camp" (considering both "Shaheed Millat Camp" and "Millat School Camp" under a single entity) and "Baganbari slum" as the 
study-units. The primary reason to choose these places as study unit is that these are the typical areas of this kind. Selecting these areas would make the survey less difficult due to the availability of a comprehensive sample-frame, prepared and made available by Dushtha Shasthya Kendra (DSK), a Nongovernmental Organization (NGO). DSK deals with "microfinancing" the poor and the socially isolates, and, to track their borrowers, they have given holding numbers to each family household who are living in the slum and camp mentioned above. Using those holding numbers as the sample frame, the study has applied systematic random sampling to select the respondents.

The Millat Camp is located in somewhat disperse manner on almost 4 acres of land at Mirpur section 11, under Pallabi Thana. There are 1065 households with an estimated population of 6620 [28]. The camp is characterized by severe overcrowding, lack of basic amenities, and unhygienic living conditions. The camp has electricity but has only one latrine for all and very few washing points. Most of the settlements are two-floor wooden building with a set of narrow steps leading upstairs. The Baganbari slum is located at the northern-west part of Dhaka city at ward number 4 of City Corporation (DCC) under section 14 of Mirpur area. It is built in 1980 and initially named Karim Mia's slum, named after the person who, along with his family, first started to live in that place. The slum is on around one acre of land owned by "Ministry of Housing and Public Works" and "Dhaka Water and Sanitation Authority." There are about 277 families, with an average of 5.5 members living in the slum. The estimated population of the slum is twelve hundred and fifty. Most of the houses are made of bamboo with a tin-made roof.

There are many studies reporting perceived social isolation or loneliness and their correlates in specific groups; however, there are hardly any modern prevalence studies of the people who are living in refugee-camp and a slum in Dhaka city. Although some issues are debatable, particularly in their relevance to studies of historical context, which reflect the common concerns of researchers in this area, this research considers few issues as significant: (1) sociopolitical situation and the pattern of networks change over time and a macrolevel analysis are needed to explain how they differ in terms of cultural setting; (2) subjective aspects of social isolation should be measured quantitatively through a wellformed and reliable scale; (3) basic demographic variables, such as age, sex, education, and occupation, need to be included in addition to sociopolitical and cultural factors; (4) social isolation may vary according to the place of living of the individual; (5) not all the elements of social isolation have the same equal importance to be focused on; (6) some elements of the social isolation scale contributes more in forming the crisis situations than others; and (7) socially excluded and poverty-stricken samples are more robust samples when measured together. There are some evidences from former studies that baseline assessments of sociopolitical situation and cultural pattern are of little value in predicting social isolation. If socially excluded and poverty-stricken samples were undertaken and compared, a more vivid picture can be made.

\section{Findings and Discussion}

Social isolation reflects both the state of the mind of an individual or group and the cultural process that often defies the communication and cooperation within the individuals of any particular society. Structurally, it is the absence of social interactions, contacts, and relationships with family and friends, with neighbors on an individual level, and with "society at large" on a broader level. It is a risk factor negatively associated with the development of the social situation of any country. A socially isolated individual can be characterized as one he feels that he has little or no influence or control over sociopolitical outcomes and who senses he cannot assert himself as subject to modify his situation.

The "Millat Camp," by all means, offers substandard living conditions for its inhabitants. It has poor drainage and garbage disposal systems. Livestock are living side by side with the community. There is hardly any economic opportunity for them, neither inside nor outside the camp. They are working primarily as hairdressers or sari-makers. Job opportunities are rare and loans for small businesses for looms and cloth are virtually nonexistent [29]. Those who manage to start a business have got to contend against the extreme transgression in the camps and need to face the resent of the Bengalis [3]. Land encroachment and forced evictions in the settlements continue to affect the community. However, despite the dreadful living conditions, their situation is not worse off than many Bangladeshis who live in poverty in similar conditions in Baganbari slum.

The residents of Baganbari slum are predominantly low income group. DSK reports that most of them either do small businesses $(17 \%)$ or work as rickshaw, van, or cart pullers (17\%) and some are private service holders (13\%), while others work as servants (13\%). A large number of the slum-dwellers are unemployed or involved in nonspecific job. Their estimated per capita income in a very few occasions reaches BDT 7736 per month (as the Bangladesh Bureau of Statistics indicates in 2014); 62 percent of the slum-dwellers earn not more than BDT 5,000 and another 27 percent of them earn less than BDT 3,000 per month. There is absolutely no educational opportunity in the slum, and a considerable number of people are illiterate. About 30 percent started their primary education but could not complete it; another 7 percent reportedly have completed their primary education but fail to complete secondary education.

These people, as segregated from the larger society, are exposed to the feeling of isolation. The root cause of their social isolation objectively lies in the absence of proper social relations. Further, the poor financial situations of the neighbor and the absence of social capital are supposed to augment the level of isolation that they are facing. Impoverished living conditions, polluted air, contaminated water, increased bureaucratization of the employment sector, and a complex matrix of other social forces of urban lives are serving to fragment their minds and segment their lives, thereby isolating them from the very society that they are part of. Given that, the interpersonal problems of the people living in Millat refugee-camp and Baganbari slum should have reached such a point that they have lost their competence 
TABLE 1: Subjective perception of feeling isolation in relation to demographic variables (in percent) $(n=384)$.

\begin{tabular}{|c|c|c|c|c|}
\hline \multirow{2}{*}{ Factor } & \multirow{2}{*}{ Level } & \multicolumn{2}{|c|}{ Social isolation } & \multirow{2}{*}{ Total } \\
\hline & & Not feeling isolated & Feeling isolated & \\
\hline \multirow{3}{*}{ Place of living } & Camp & 56.1 & 43.9 & 100.0 \\
\hline & Slum & 47.4 & 52.6 & 100.0 \\
\hline & Total & 49.9 & 50.1 & 100.0 \\
\hline \multirow{3}{*}{ Sex } & Male & 48.9 & 51.1 & $\overline{100.0}$ \\
\hline & Female & 53.7 & 46.3 & 100.0 \\
\hline & Total & 49.9 & 50.1 & 100.0 \\
\hline \multirow{5}{*}{ Education } & Illiterate & 47.7 & 52.3 & 100.0 \\
\hline & Primary & 46.7 & 53.3 & 100.0 \\
\hline & Secondary & 61.6 & 38.4 & 100.0 \\
\hline & Higher Secondary & 16.7 & 83.3 & 100.0 \\
\hline & Total & 49.9 & 50.1 & 100.0 \\
\hline \multirow{9}{*}{ Occupation } & Hawker & 51.1 & 48.9 & 100.0 \\
\hline & Rickshaw Puller & 46.0 & 54.0 & 100.0 \\
\hline & Daily Unskilled Labor & 38.9 & 61.1 & 100.0 \\
\hline & Contractual Unskilled Labor & 61.9 & 38.1 & 100.0 \\
\hline & House Wife & 55.6 & 44.4 & 100.0 \\
\hline & SME & 54.7 & 45.3 & 100.0 \\
\hline & Skilled Labor & 36.7 & 63.3 & 100.0 \\
\hline & Out of Work & 57.1 & 42.9 & 100.0 \\
\hline & Total & 49.9 & 50.1 & 100.0 \\
\hline \multirow{7}{*}{ Age } & Below 20 & 56.0 & 44.0 & 100.0 \\
\hline & $20-29$ & 52.8 & 47.2 & 100.0 \\
\hline & $30-39$ & 44.6 & 55.4 & 100.0 \\
\hline & $40-49$ & 50.0 & 50.0 & 100.0 \\
\hline & $50-59$ & 57.1 & 42.9 & 100.0 \\
\hline & 60 and Above & 33.3 & 66.7 & 100.0 \\
\hline & Total & 49.9 & 50.1 & 100.0 \\
\hline
\end{tabular}

Source: survey data.

of functioning in interpersonal relationships and therefore begin to perceive themselves as socially isolated.

"Social isolation" subscale of "powerlessness scale" provided by Dean has been devised to measure the extent to which social isolation exists among these people. The study has found that 52.6 percent of the slum dwellers are feeling isolated, whereas 56.1 percent of the camp dwellers are not feeling isolated. While, considering gender, 51.1 percent of the males are feeling isolated, 46.3 percent females are reportedly feeling isolated. For those who have completed their higher secondary education, 83.3 percent of them are feeling socially isolated, whereas 83.3 percent of those who have not reached the higher secondary mark are not feeling socially isolated. Considering the occupation, 61.9 percent of the contractual labors, 54.7 percent of the "small \& medium enterprise" owners, 57.1 percent of the unemployed, and 55.6 percent of the housewives are not feeling socially isolated, whereas 63.3 percent of the skilled labors, and 61.1 percent of the unskilled labors are feeling isolated (for details, see Table 1).

The living condition in a refugee camp and a slum would be marginally different or not different at all. The study attempts to compare the level of isolation in different places of living. It has been found that 34.5 percent of camp dwellers, who are not feeling isolated, belong to twenty-to-twentynine age bracket, and 23.3 percent of those who are feeling isolated are from thirty to thirty-nine of age. The scenario is a bit different with the slum dwellers. About one-third of the slum dwellers, who are feeling isolated, are between twenty and twenty-nine of age. Nearly about eighty-three percent of slum dwellers, who are feeling isolated, are males, whereas nearly about seventeen percent of them who are feeling isolated are females. Majority among the people who are feeling isolated, 69.8 percent of the people from camp, and 47.0 percent of the people from the slum are illiterate. Noticeably, only 2.3 percent of the camp-dwellers and 6.8 percent of the slum-dwellers, who are feeling isolated, have completed their higher secondary education. Approximately, thirty-five percent of the socially isolated of the camp dwellers are involved in skilled labor, whereas, for the slum dwellers who are feeling isolated, 51.5 percent of them are hawkers (for details, see Table 2).

The study has not found any statistically significant relation between the demographic variables and social isolation variable. However, it has, indeed, found some significant 
TABLE 2: Comparative scenario of social isolation in relation to place of living (in percent) $(n=384)$.

\begin{tabular}{|c|c|c|c|c|c|}
\hline \multirow{2}{*}{ Factor } & \multirow{2}{*}{ Level } & \multicolumn{2}{|c|}{ Camp } & \multicolumn{2}{|c|}{ Slum } \\
\hline & & Not feeling isolated & Feeling isolated & Not feeling isolated & Feeling isolated \\
\hline \multirow{7}{*}{ Age } & Below 20 & 10.9 & 14.0 & 18.5 & 12.1 \\
\hline & $20-29$ & 34.5 & 16.3 & 31.9 & 33.3 \\
\hline & $30-39$ & 18.2 & 23.3 & 22.7 & 27.3 \\
\hline & $40-49$ & 21.8 & 16.3 & 17.6 & 19.7 \\
\hline & $50-59$ & 5.5 & 11.6 & 7.6 & 3.0 \\
\hline & 60 and Above & 9.1 & 18.6 & 1.7 & 4.5 \\
\hline & Total & 100.0 & 100.0 & 100.0 & 100.0 \\
\hline \multirow{3}{*}{ Sex } & Male & 80.0 & 79.1 & 79.0 & 83.3 \\
\hline & Female & 20.0 & 20.9 & 21.0 & 16.7 \\
\hline & Total & 100.0 & 100.0 & 100.0 & 100.0 \\
\hline \multirow{5}{*}{ Education } & Illiterate & 58.1 & 69.8 & 43.7 & 47.0 \\
\hline & Primary & 16.4 & 20.9 & 21.8 & 23.5 \\
\hline & Secondary & 25.5 & 7.0 & 32.8 & 22.7 \\
\hline & Higher Secondary & 0.0 & 2.3 & 1.7 & 6.8 \\
\hline & Total & 100.0 & 100.0 & 100.0 & 100.0 \\
\hline \multirow{9}{*}{ Occupation } & Hawker & 3.6 & 0.0 & 58.0 & 51.5 \\
\hline & Rickshaw Puller & 12.7 & 14.0 & 18.5 & 21.2 \\
\hline & Daily Unskilled Labor & 1.8 & 7.0 & 5.0 & 6.1 \\
\hline & Contractual Unskilled Labor & 12.7 & 11.6 & 5.0 & 2.3 \\
\hline & House Wife & 10.9 & 7.0 & 3.4 & 3.8 \\
\hline & SME & 32.7 & 23.3 & 9.2 & 10.6 \\
\hline & Skilled Labor & 18.2 & 34.9 & 0.8 & 3.0 \\
\hline & Out of Work & 7.3 & 2.3 & 0.0 & 1.5 \\
\hline & Total & 100.0 & 100.0 & 100.0 & 100.0 \\
\hline
\end{tabular}

Source: survey data.

relations between "place of living" and some selected items (for details, see Table 3):

(1) Exactly half $(9.2 \%+40.8 \%=50 \%)$ of the camp dwellers accept that most people rarely feel lonely. On the other hand just over one-third $(11.6 \%+23.5 \%=$ $35.1 \%$ ) of the slum dwellers accept this. Thus, camp dwellers accept that feeling loneliness is less common.

(2) A significant percent $(12.2 \%+33.7 \%=45.9 \%)$ of camp dwellers feel that real friends are easy to find, whereas less than one-third $(12.4 \%+17.1 \%=29.5 \%)$ of the slum dwellers have agreed to this.

(3) A majority $(30.3 \%+30.3 \%=60.6 \%)$ of slum dwellers and almost half $(14.3 \%+33.7 \%=48 \%)$ of the camp dwellers do not get to visit friends as often as they would really like.

(4) Most of the respondents, both from the camp $(7.1 \%$ $+50.0 \%=57.1 \%)$ and slum $(35.5 \%+29.5 \%=65 \%)$, accept that one can always find friends if he shows himself friendly.

Though there is no significant difference in terms of overall responses, as mentioned earlier, however, some significant relations are being found between the occupation of the respondent and certain statements (for details, see Table 4):

(1) Majority of the rickshaw puller $(25.4 \%+39.7 \%=$ $65.1 \%)$, hawkers $(24.5 \%+36.7 \%=61.2 \%)$, and daily unskilled labor $(5.6 \%+55.6 \%=61.2 \%)$ fail to accept that real friends are as easy as ever to find. Overall, only nearly about one-third of $(12.3 \%+21.8 \%=$ $34.1 \%)$ all the respondents accepted the facts it is always easy to find real friends.

(2) Overwhelming majority of the rickshaw puller $(39.7 \%$ $+42.9 \%=82.6 \%$ ) accepted that one can always find friends if he shows himself friendly. The majority of the housewives $(16.7 \%+55.6 \%=72.3 \%)$ also accepted this fact.

(3) More than half of the rickshaw pullers $(25.4 \%+$ $34.9 \%=60.3 \%$ ) accepted that they did not get invited out by the friends as often as they would like. Not surprisingly, more than half of the housewives $(38.9 \%$ $+22.2 \%=61.1 \%$ ) did not accept this.

Given that both the slam dwellers and the people who are living in the camp properly responded to the statement asked and adequately considered on the associated variables of Dean's scale of social isolation, considering the strength, the results suggest the following subjective outcomes:

(1) People who sometimes feel all alone in the world, they believe that people rarely feel lonely today $(r=0.328)$. Further, they consider that the world, in which they live, is basically a friendly place $(r=0.132)$. 
TABLE 3: Statistically significant relations between "place of living" and selected "statements \& responses" (in percent) ( $n=384)$.

\begin{tabular}{|c|c|c|c|c|c|c|c|}
\hline \multirow{2}{*}{ Place of Living } & \multicolumn{5}{|c|}{ Statements and responses } & \multirow{2}{*}{ Total } & \multirow{2}{*}{ Statistics } \\
\hline & Strongly Agree & Agree & Uncertain & Disagree & Strongly Disagree & & \\
\hline \multicolumn{8}{|c|}{ Most people today rarely feel lonely } \\
\hline Camp & 9.2 & 40.8 & 21.4 & 23.5 & 5.1 & 100.0 & \multirow{3}{*}{$\begin{array}{l}\chi^{2}=11.670 \\
\mathrm{df}=4 \\
\alpha=0.05\end{array}$} \\
\hline Slum & 11.6 & 23.5 & 26.7 & 27.1 & 11.2 & 100.0 & \\
\hline Total & 10.9 & 28.4 & 25.2 & 26.1 & 9.5 & 100.0 & \\
\hline \multicolumn{8}{|c|}{ Real friends are as easy as ever to find } \\
\hline Camp & 12.2 & 33.7 & 14.3 & 22.4 & 17.3 & 100.0 & \multirow{3}{*}{$\begin{array}{l}\chi^{2}=20.671 \\
\mathrm{df}=4 \\
\alpha=0.001\end{array}$} \\
\hline Slum & 12.4 & 17.1 & 9.2 & 22.3 & 39.0 & 100.0 & \\
\hline Total & 12.3 & 21.8 & 10.6 & 22.3 & 33.0 & 100.0 & \\
\hline \multicolumn{8}{|c|}{ I don't get to visit friends as often as I'd really like } \\
\hline Camp & 14.3 & 33.7 & 13.3 & 25.5 & 13.3 & 100.0 & \multirow{3}{*}{$\begin{array}{l}\chi^{2}=16.149 \\
\mathrm{df}=4 \\
\alpha=0.005\end{array}$} \\
\hline Slum & 30.3 & 30.3 & 17.9 & 14.3 & 7.2 & 100.0 & \\
\hline Total & 25.8 & 31.2 & 16.6 & 17.5 & 8.9 & 100.0 & \\
\hline \multicolumn{8}{|c|}{ One can always find friends if he shows himself friendly } \\
\hline Camp & 7.1 & 50.0 & 12.2 & 21.4 & 9.2 & 100.0 & \multirow{3}{*}{$\begin{array}{l}\chi^{2}=32.336 \\
\mathrm{df}=4 \\
\alpha=0.001\end{array}$} \\
\hline Slum & 35.5 & 29.5 & 14.3 & 13.5 & 7.2 & 100.0 & \\
\hline Total & 27.5 & 35.2 & 13.8 & 15.8 & 7.7 & 100.0 & \\
\hline
\end{tabular}

Source: survey data.

TABLE 4: Statistically significant relations between occupation and selected “statements \& responses" (in percent) $(n=384)$.

\begin{tabular}{|c|c|c|c|c|c|c|c|}
\hline \multirow{2}{*}{ Occupation } & \multicolumn{5}{|c|}{ Statements and responses } & \multirow{2}{*}{ Total } & \multirow{2}{*}{ Statistics } \\
\hline & Strongly Agree & Agree & Uncertain & Disagree & Strongly Disagree & & \\
\hline \multicolumn{8}{|c|}{ Real friends are as easy as ever to find } \\
\hline Hawker & 12.9 & 14.4 & 11.5 & 24.5 & 36.7 & 100.0 & \multirow{9}{*}{$\begin{array}{l}\chi^{2}=46.937 \\
\mathrm{df}=28 \\
\alpha=0.05\end{array}$} \\
\hline Rickshaw Puller & 9.5 & 22.2 & 3.2 & 25.4 & 39.7 & 100.0 & \\
\hline Daily Unskilled Labor & 16.7 & 16.7 & 5.6 & 5.6 & 55.6 & 100.0 & \\
\hline Contractual Unskilled Labor & 14.3 & 33.3 & 9.5 & 23.8 & 19.0 & 100.0 & \\
\hline House Wife & 0.0 & 38.9 & 16.7 & 5.6 & 38.9 & 100.0 & \\
\hline SME & 13.2 & 34.0 & 7.5 & 24.5 & 20.8 & 100.0 & \\
\hline Skilled Labor & 20.0 & 16.7 & 20.0 & 23.3 & 20.0 & 100.0 & \\
\hline Out of Work & 0.0 & 28.6 & 42.9 & 14.3 & 14.3 & 100.0 & \\
\hline Total & 12.3 & 21.8 & 10.6 & 22.3 & 33.0 & 100.0 & \\
\hline \multicolumn{8}{|c|}{ One can always find friends if he or she shows himself friendly } \\
\hline Hawker & 34.5 & 29.5 & 17.3 & 12.9 & 5.8 & 100.0 & \multirow{9}{*}{$\begin{array}{l}\chi^{2}=50.795 \\
\mathrm{df}=28 \\
\alpha=0.005\end{array}$} \\
\hline Rickshaw Puller & 39.7 & 42.9 & 0.0 & 9.5 & 7.9 & 100.0 & \\
\hline Daily Unskilled Labor & 27.8 & 16.7 & 16.7 & 27.8 & 11.1 & 100.0 & \\
\hline Contractual Unskilled Labor & 23.8 & 38.1 & 14.3 & 19.0 & 4.8 & 100.0 & \\
\hline House Wife & 16.7 & 55.6 & 0.0 & 11.1 & 16.7 & 100.0 & \\
\hline SME & 11.3 & 32.1 & 20.8 & 24.5 & 11.3 & 100.0 & \\
\hline Skilled Labor & 10.0 & 46.7 & 20.0 & 20.0 & 3.3 & 100.0 & \\
\hline Out of Work & 14.3 & 42.9 & 14.3 & 14.3 & 14.3 & 100.0 & \\
\hline Total & 27.5 & 35.2 & 13.8 & 15.8 & 7.7 & 100.0 & \\
\hline \multicolumn{8}{|c|}{ I don't get invited out by friends as often as I'd really like } \\
\hline Hawker & 19.4 & 22.3 & 10.1 & 29.5 & 18.7 & 100.0 & \multirow{9}{*}{$\begin{array}{l}\chi^{2}=36.115 \\
\mathrm{df}=28 \\
\alpha=0.05\end{array}$} \\
\hline Rickshaw Puller & 25.4 & 34.9 & 15.9 & 15.9 & 7.9 & 100.0 & \\
\hline Daily Unskilled Labor & 27.8 & 16.7 & 11.1 & 16.7 & 27.8 & 100.0 & \\
\hline Contractual Unskilled Labor & 33.3 & 14.3 & 4.8 & 28.6 & 19.0 & 100.0 & \\
\hline House Wife & 22.2 & 11.1 & 5.6 & 38.9 & 22.2 & 100.0 & \\
\hline SME & 7.5 & 34.0 & 17.0 & 22.6 & 18.9 & 100.0 & \\
\hline Skilled Labor & 33.3 & 20.0 & 6.7 & 26.7 & 13.3 & 100.0 & \\
\hline Out of Work & 14.3 & 42.9 & 0.0 & 42.9 & 0.0 & 100.0 & \\
\hline Total & 21.2 & 25.2 & 11.2 & 25.8 & 16.6 & 100.0 & \\
\hline
\end{tabular}

Source: survey data. 
TABLE 5: Inter-item correlation matrix.

\begin{tabular}{|c|c|c|c|c|c|c|c|c|}
\hline & $\begin{array}{l}\text { I don't get } \\
\text { invited out by } \\
\text { friends as } \\
\text { often as I'd } \\
\text { really like }\end{array}$ & $\begin{array}{l}\text { Most } \\
\text { people } \\
\text { today } \\
\text { rarely feel } \\
\text { lonely }\end{array}$ & $\begin{array}{l}\text { Real friends } \\
\text { are as easy } \\
\text { as ever to } \\
\text { find }\end{array}$ & $\begin{array}{l}\text { One can } \\
\text { always find } \\
\text { friends if he } \\
\text { shows } \\
\text { himself } \\
\text { friendly }\end{array}$ & $\begin{array}{l}\text { The world in } \\
\text { which we live } \\
\text { is basically a } \\
\text { friendly place }\end{array}$ & $\begin{array}{l}\text { There are few } \\
\text { dependable } \\
\text { ties between } \\
\text { people any } \\
\text { more }\end{array}$ & $\begin{array}{l}\text { People are } \\
\text { just naturally } \\
\text { friendly and } \\
\text { helpful }\end{array}$ & $\begin{array}{l}\text { I don't get to } \\
\text { visit friends } \\
\text { as often as I'd } \\
\text { really like }\end{array}$ \\
\hline $\begin{array}{l}\text { Sometimes I feel all } \\
\text { alone in the world }\end{array}$ & 0.029 & $0.328^{* *}$ & -0.029 & 0.102 & $0.132^{*}$ & -0.049 & 0.059 & -0.038 \\
\hline $\begin{array}{l}\text { I don't get invited out } \\
\text { by friends as often as } \\
\text { I'd really like }\end{array}$ & & -0.055 & 0.002 & $0.164^{* *}$ & 0.057 & 0.044 & 0.046 & $0.217^{* *}$ \\
\hline $\begin{array}{l}\text { Most people today } \\
\text { rarely feel lonely }\end{array}$ & & & -0.018 & -0.033 & -0.032 & 0.026 & 0.056 & -0.007 \\
\hline $\begin{array}{l}\text { Real friends are as } \\
\text { easy as ever to find }\end{array}$ & & & & $0.162^{* *}$ & $0.173^{* *}$ & $-0.120^{*}$ & $0.198^{* *}$ & 0.063 \\
\hline $\begin{array}{l}\text { One can always find } \\
\text { friends if he shows } \\
\text { himself friendly }\end{array}$ & & & & & $0.265^{* *}$ & -0.053 & $0.197^{* *}$ & $-0.105^{*}$ \\
\hline $\begin{array}{l}\text { The world in which } \\
\text { we live is basically a } \\
\text { friendly place }\end{array}$ & & & & & & $-0.213^{* *}$ & $0.328^{* *}$ & -0.096 \\
\hline $\begin{array}{l}\text { There are few } \\
\text { dependable ties } \\
\text { between people any } \\
\text { more }\end{array}$ & & & & & & & $-0.171^{* *}$ & $0.146^{* *}$ \\
\hline $\begin{array}{l}\text { People are just } \\
\text { naturally friendly and } \\
\text { helpful }\end{array}$ & & & & & & & & -0.056 \\
\hline
\end{tabular}

${ }^{* *}$ Correlation is significant at the 0.01 level (2-tailed).

${ }^{*}$ Correlation is significant at the 0.05 level (2-tailed).

Source: survey data.

(2) Those who do not get invited by their friends as much as they like, do not visit their friends as often as they feel they should $(r=0.217)$. However, they feel that they can have friends if they show themselves friendly $(r=0.164)$.

(3) Those who believe that real friends are easy to find feel that one can always find friends if he shows himself friendly $(r=0.162)$. They consider the world is a friendly place $(r=0.173)$ and people are just naturally friendly and helpful $(r=0.198)$. They do not believe that there are few dependable ties between people any more $(r=0.120)$.

(4) Those who consider that one can always find friends if he shows friendly behavior believe that real friends can be easily found $(r=0.265)$. They believe that people are naturally friendly and helpful $(r=0.197)$. Expectedly, they get to visit friends as often as they like $(r=0.105)$.

(5) Those who consider the world,as basically a friendly place do not consider that there are few dependable ties between people any more $(r=0.213)$. They believe that people are just naturally friendly and helpful $(r=0.328)$.

(6) Those who believe that there are few dependable ties between people any more do not consider that people are just naturally friendly and helpful $(r=0.171)$. They are the people who do get to visit friends as often as they would like to visit $(r=0.146)$.

This also suggests that Dean's measures of social isolation that incorporate different dimensions of social isolation and perceived inadequacy of one's social relations, to wide extent, successfully measure what they actually intended to measure (For detail, see Table 5).

The degree of association with the social isolation variable and the independent items of measurement can reveal which variable is predominantly contributing to social isolation. All the positive statements have strong association with social isolation variable. Believing that "people are just naturally friendly and helpful" has the strongest correlation $(r=$ 0.428 ) with "isolation variable." The other strong association is found between believing "the world in which we live is basically a friendly place $(r=0.411)$." On the other hand, feelings like "most of the people today rarely feel lonely $(r=$ $0.128)$ " and "there are few dependable ties between people any more $(r=0.143)$ " are negligibly associated (for details, see Table 6).

\section{Conclusions}

The consequence of the feelings of social isolation lies in the implication of the perceived social situation and available 
TABLE 6: Value of Pearson correlation $(r)$ between the items and "social isolation" variable.

\begin{tabular}{lcc}
\hline Statement(s) & Value of Pearson correlation $(r)$ & Level of significance $(\alpha)$ \\
\hline People are just naturally friendly and helpful & 0.428 & 0.01 \\
The world in which we live is basically a friendly place & 0.411 & 0.01 \\
Real friends are as easy as ever to find & 0.401 & 0.01 \\
One can always find friends if he shows himself friendly & 0.385 & 0.01 \\
I don't get invited out by friends as often as I'd really like & 0.307 & 0.01 \\
I don't get to visit friends as often as I'd really like & 0.267 & 0.01 \\
Sometimes I feel all alone in the world & 0.213 & 0.01 \\
There are few dependable ties between people any more & 0.143 & 0.01 \\
Most people today rarely feel lonely & 0.128 & 0.05 \\
\hline
\end{tabular}

Source: survey data.

social relations around the people. In another way to say it, social isolation is inversely associated with the learning of information relevant to one's interpersonal security. Hence, the assumption that social relations are associated with overall well-being and the fact that social isolation is linked to the expectation to the development of a feeling of inadequately connected to the wider society make the importance of subjective perception of the individuals evidently clear. The empirical findings seek to correlate social isolation variable with parity in both poor and socially excluded people simultaneously controlling for age, sex, education, and occupation. There were no differences in powerlessness between these two groups. The data do not support the notion there is a difference in the situation of socially excluded group of people and people who are poor and hence is compatible with the hypothesis that there is hardly any difference in the perceived isolation regarding the economic situation and socially excluded people who are living a segregated area.

The research shows the effects of age, sex, education, occupation, and place of living on social isolation. Using primary survey data from households in refugee-camp and a slum in Dhaka city, the study indicates a comparison between isolates and nonisolates. It is found that slightly over half of the slum dwellers are feeling isolated, whereas slightly over half of the camp dwellers are not feeling isolated. This indicates that the greater part of the slum-dwellers is feeling isolated, whereas lesser part of the camp-dwellers feels isolated. Females are less likely than males and old people are more likely than young ones to show the feeling of isolation. Completion of higher secondary education increases the feeling of isolation. Those who have completed their higher secondary education are more vulnerable to the feeling of isolation, whereas those who have not reached the higher secondary mark are less vulnerable. The nature of the job also contributes to the feeling of isolation. More than half of the contractual labors, "small \& medium enterprise" owners, the unemployed, and housewives are not feeling socially isolated, whereas over half of the labors, both skilled and unskilled, are feeling isolated. Predominantly, daily unskilled labor feels isolated, and contractual unskilled labors are less exposed to the feeling of isolation.

In addition to perceived social isolation assessed by Dean's Scale, data that were collected on sociodemographic variables was also used to compare the relative differences between the camp and slum dwellers. While comparing the place of living, it has been found that slightly above onethird of camp dwellers, who are not feeling isolated, belong to twenty-to-twenty-nine age bracket, and almost one-fourth of those who are feeling isolated are from thirty to thirtynine of age. About one-third of the slum dwellers, who are between twenty and twenty-nine of age, are feeling isolated. The research finds the predominance of males in relation to social isolation variable. The majority of the people, both from the camp and from the slum, who are feeling isolated are illiterate. The least percentage of feeling of isolation belongs to the people who have not reached the completion of their higher secondary education. Somewhat one-third of the socially isolated of the camp dwellers are involved in skilled labor, whereas, for those of the slum dwellers who are feeling isolated, nearly half of them are hawkers.

The findings suggest that the key factors that are associated with the feeling of isolation are believing that (a) people are just naturally friendly and helpful; (b) the world in which we live is basically a friendly place; and (c) real friends are as easy as ever to find and one can always find friends if he shows himself friendly. Thus, it can be concluded that the person who feels that there is something to be gained by activity is more apt to act.

\section{Conflict of Interests}

The author declares that there is no conflict of interests regarding the publication of this paper.

\section{References}

[1] H. Sholder, Housing and Land Rights, The Camp-Dwelling UrduSpeaking Community in Bangladesh, Refugee and Migratory Movements Research Unit (RMMRU), Dhaka, Bangladesh, 2011.

[2] A. M. A. Muhith, Bangladesh: Emergence of a Nation, Bangladesh Book International, Dhaka, Bangladesh, 1978.

[3] E. Paulsen, "The citizenship status of the Urdu-speakers/Biharis in Bangladesh," Refugee Survey Quarterly, vol. 25, no. 3, pp. 5469, 2006. 
[4] C. E. Haque, "Non-Bengali refugees in Bangladesh: patterns, policies and consequences," in Refugees: A Third World Dilemma, J. Rogge, Ed., Rowman \& Littlefield Press, Totowa, NJ, USA, 1987.

[5] K. F. Farzana, "The neglected stateless Bihari community in Bangladesh: victims of political and diplomatic onslaught," Journal of Humanities and Social Sciences, vol. 2, no. 1, pp. 1-19, 2008.

[6] Bangladesh Bureau of Statistics, Statistical Pocketbook Bangladesh 2007, Bangladesh Bureau of Statistics, Planning Division, Ministry of Planning, Government of the Peoples Republic of Bangladesh, Dhaka, Bangladesh, 2007.

[7] L. Friedman, "A city exploding with climate migrants. Bangladesh and climate migration, climate wire," Environment \& Energy (E\&E), 2009, http://www.eenews.net/public/climatewire/2009/03/16/1.

[8] M. Peter, Slums of Urban Bangladesh: Mapping and Census, 2005, Centre for Urban Studies, National Institute of Population Research and Training, and MEASURE Evaluation, Dhaka, Bangladesh, 2006.

[9] World Bank, Bangladesh-Dhaka: Improving Living Conditions for the Urban Poor, World Bank, Washington, DC, USA, 2007, http://documents.worldbank.org/curated/en/2007/04/7606435 /bangladesh-dhaka-improving-living-conditions-urban-poor.

[10] Aparajeyo, Slum Observatory: A Study on the Slums of Dhaka City, Aparajeyo Bangladesh, Dhaka, Bangladesh, 2005.

[11] J. L. Baker, Dhaka: Improving Living Conditions for the Urban Poor, Bangladesh Development Series, World Bank, Washington, DC, USA, 2007.

[12] F. A. S. Jensen, "Psychological aspects of the social isolation of refugees," International Migration Digest, vol. 3, no. 1, pp. 40-60, 1966.

[13] L. Wirth, "Urbanism as a way of life," The American Journal of Sociology, vol. 44, no. 1, pp. 1-24, 1938.

[14] P. A. Sorokin, Social Mobility, Harper \& Brothers, New York, NY, USA, 1927.

[15] M. McPherson, L. Smith-Lovin, and M. E. Brashears, "Social isolation in America: changes in core discussion networks over two decades," American Sociological Review, vol. 71, no. 3, pp. 353-375, 2006.

[16] D. Gallie, S. Paugam, and S. Jacobs, "Unemployment, poverty and social isolation: is there a vicious circle of social exclusion?" European Societies, vol. 5, no. 1, pp. 1-32, 2003.

[17] K. S. Rook, "Research on social support, loneliness, and social isolation: toward an integration," in Review of Personality \& Social Psychology, vol. 5, pp. 239-264, Sage, 1984.

[18] J. R. Elliott, "Social isolation and labor market insulation," The Sociological Quarterly, vol. 40, no. 2, pp. 199-216, 1999.

[19] R. L. Kahn and T. C. Antonucci, "Convoys of social support: a life-course approach," in Aging: Social Change, S. B. Kiesler, J. N. Morgan, and V. K. Oppenheimer, Eds., pp. 383-405, Academic Press, New York, NY, USA, 1981.

[20] D. Vandervoort, "Social Isolation and Gender," Current Psychology, vol. 19, no. 3, pp. 229-236, 2000.

[21] D. S. Davis, "Good people doing dirty work: a study of social isolation," Symbolic Interaction, vol. 7, no. 2, pp. 233-247, 1984.

[22] E. G. Jaco, "The social isolation hypothesis and schizophrenia," American Sociological Review, vol. 19, no. 5, pp. 567-577, 1954.

[23] M. Seeman, "On the meaning of alienation," American Sociological Review, vol. 24, no. 6, pp. 783-791, 1959.
[24] D. G. Dean, "Alienation: its meaning and measurement," American Sociological Review, vol. 26, no. 5, pp. 753-758, 1961.

[25] F. B. Waisanen, "Stability, alienation, and change," The Sociological Quarterly, vol. 4, no. 1, pp. 18-30, 1963.

[26] R. S. Weiss, Loneliness: The Experience of Emotional and Social Isolation, US: The MIT Press, Cambridge, Mass, USA, 1973.

[27] C. S. Fischer, "On urban alienations and anomie: powerlessness and social isolation," American Sociological Review, vol. 38, no. 3, pp. 311-326, 1973.

[28] G. Angeles, P. Lance, J. Barden-O'Fallon, N. Islam, A. Q. M. Mahbub, and N. I. Nazem, "The 2005 census and mapping of slums in Bangladesh: design, select results and application," International Journal of Health Geographics, vol. 8, no. 32, 2009.

[29] M. Lynch and T. Cook, Stateless Biharis in Bangladesh: A Humanitarian Nightmare, Refugees International Bulletin, 2004, http://www.refugeesinternational.org. 


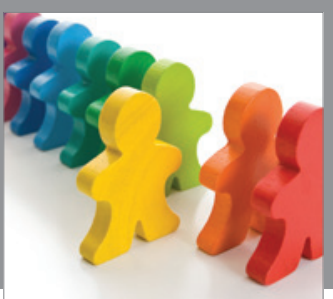

Autism

Research and Treatment
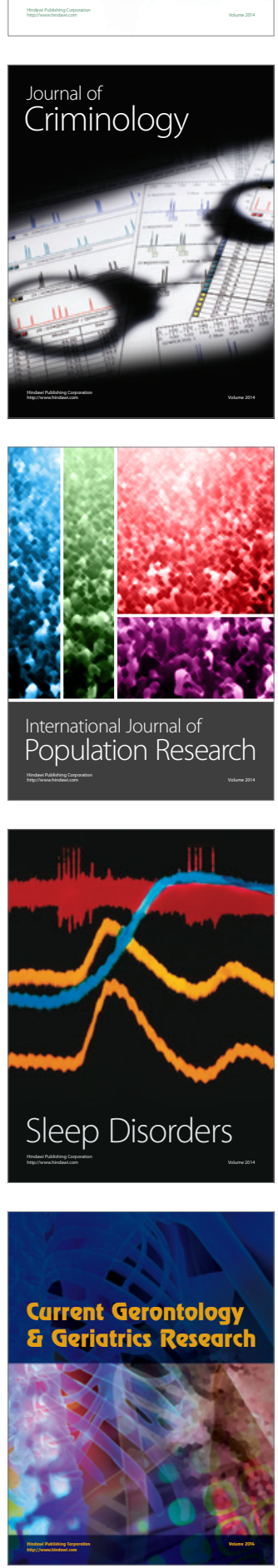

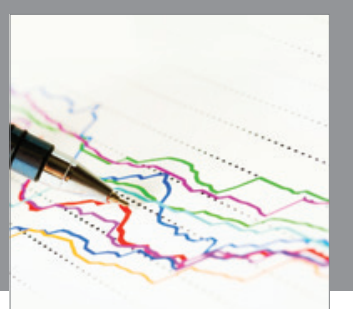

Economics

Research International
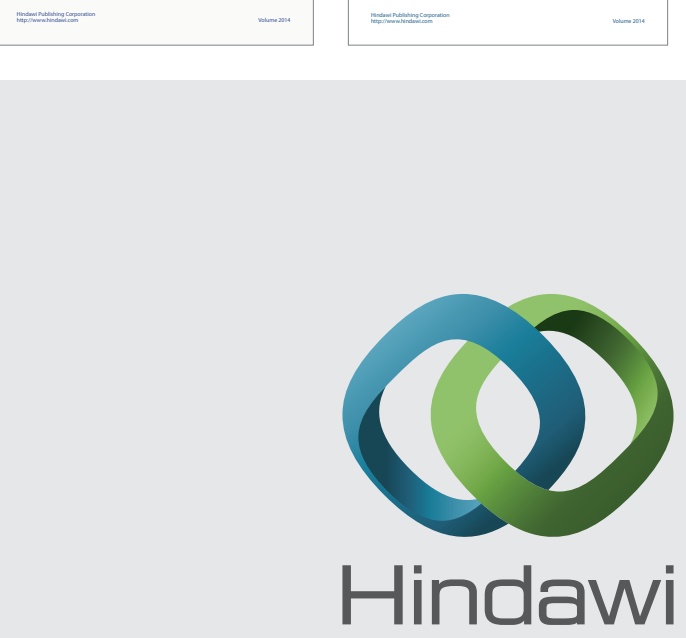

Submit your manuscripts at

http://www.hindawi.com
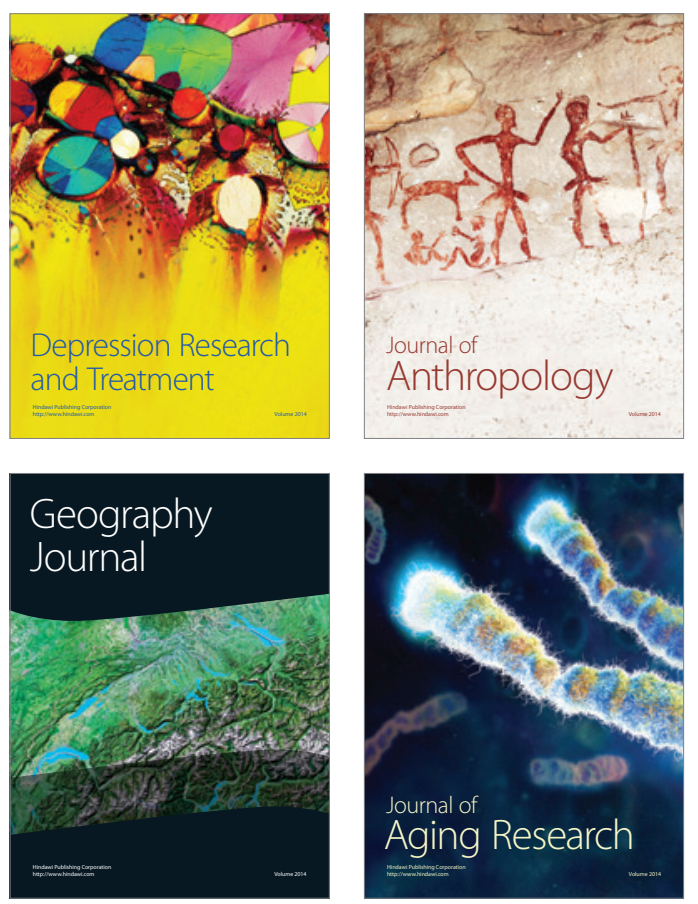
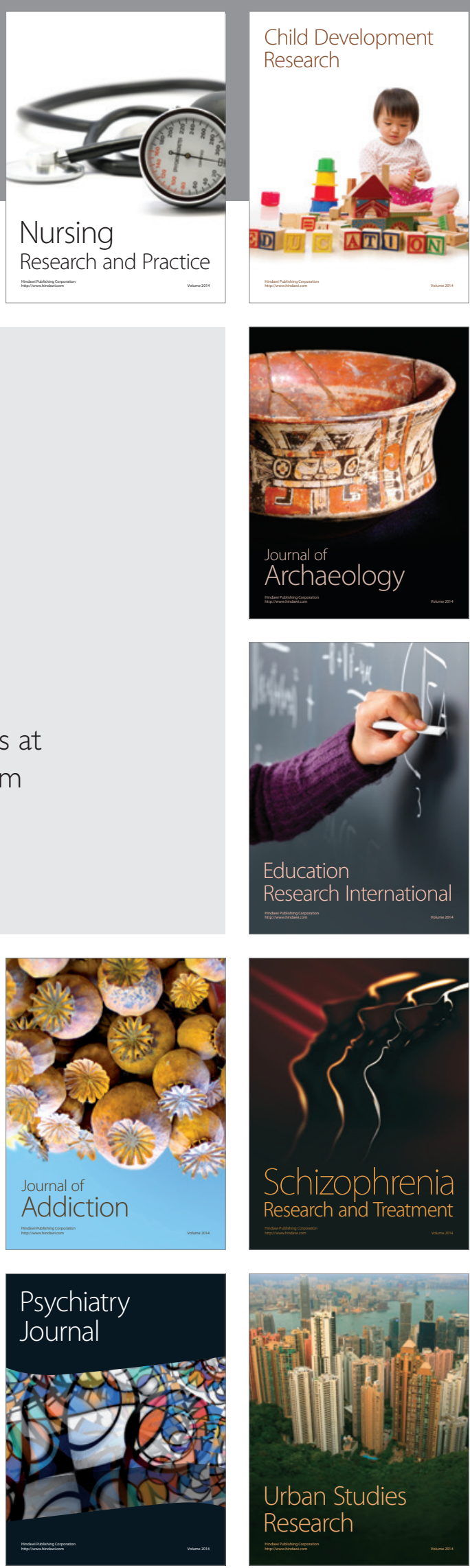